Penerbit:

Program Studi Magister Ilmu Kesehatan Masyarakat, Program Pascasarjana, Universitas Sam Ratulangi

Indonesian Journal of Public Health and Community Medicine is indexed by Google Scholar and licensed under a Creative Commons Attribution 4.0 International License.

\title{
Persepsi Masyarakat tentang Pelaksanaan Kebijakan Pemerintah tentang Pencegahan Corona Virus Disease 2019 di Kecamatan Tikala Kota Manado
}

\author{
Jeini Ester Nelwan*, Ester Candrawati Musa \\ Fakultas Kesehatan Masyarakat Universitas Sam Ratulangi \\ *E-mail: jeini_ester83@unsrat.ac.id
}

\begin{abstract}
Abstrak
Latar Belakang: Pemerintah menetapkan berbagai kebijakan dalam rangka pengendalian penyebaran Corona Virus Disease 2019 (Covid-19). Namun upaya ini belum berjalan maksimal sehingga masih ditemukan masyarakat yang melanggar protokol kesehatan yang berdampak pada peningkatan kasus Covid-19. Tujuan penelitian ini yaitu untuk menggambarkan persepsi masyarakat tentang pelaksanaan kebijakan pemerintah tentang pencegahan Covid-19 di Kecamatan Tikala Kota Manado. Metode Penelitian: Penelitian ini termasuk studi observasional dengan rancangan penelitian cross sectional study. Penelitian ini dilaksanakan di Kecamatan Tikala Kota Manado pada Agustus 2020. Subyek dalam penelitian ini yaitu 100 kepala keluarga keluarga yang memenuhi kriteria inklusi. Variabel penelitian ini yaitu persepsi masyarakat tentang pelaksanaan kebijakan pemerintah dalam upaya pencegahan Covid-19. Data hasil penelitian dianalisis secara univariat. Penyajian data dibuat dalam bentuk tabel dan narasi. Hasil Penelitian: Hasil penelitian ini menunjukkan bahwa sebanyak 10\% masyarakat menilai bahwa pemerintah telah melaksanakan kebijakan dalam upaya pencegahan Covid 19. Kebijakan yang paling rendah nilainya yaitu upaya sosialisasi kepada masyarakat tentang Covid-19. Selain itu, pengawasan pemerintah tentang penggunaan masker, pengukuran suhu tubuh dan kepemilikan dokumen sehat dari institusi kesehatan dari masyarakat yang masih sekitar $11 \%$. Hal ini mengindikasikan upaya pemerintah masih belum maksimal dalam pelaksaan kebijakan tentang pencegahan Covid-19. Kesimpulan: Kesimpulan penelitian ini yaitu pemerintah belum melakukan kebijakan pencegahan Covid-19 dengan baik khususnya dalam upaya sosialisasi dan pengawasan. Oleh karena itu harus dilakukan upaya sosialisasi dan pengawasan secara masif dan dilakukan secara bersama oleh pemerintah dan seluruh stakeholder yang ada di wilayah tersebut agar dapat menekan laju peningkatan Covid 19.
\end{abstract}

Kata Kunci: persepsi masyarakat; kebijakan pemerintah; Covid-19 


\begin{abstract}
Background: The government has set various policies in order to control the spread of Corona Virus Disease 2019 (Covid-19). However, these efforts have not run optimally so that people who violate health protocols are still found which have an impact on increasing cases of Covid-19. The purpose of this study is to describe the public's perception of the implementation of government policies regarding the prevention of Covid-19 in Tikala District, Manado City.. Methode: This study was an observational study with a cross sectional study design. This research was conducted in Tikala District, Manado City in August 2020. The subjects in this study were 100 family heads who met the inclusion criteria. The research variable is the public's perception of the implementation of government policies in an effort to prevent Covid-19. The research data were analyzed by univariate. Presentation of data is made in table and narrative form. Result: The results of this study indicate that as many as $10 \%$ of the public think that the government has implemented policies in an effort to prevent Covid 19. The policies with the lowest value are efforts to disseminate information to the public about Covid-19. In addition, government supervision of the use of masks, measuring body temperature and ownership of health documents from health institutions from the public is still around $11 \%$. This indicates that the government's efforts are still not maximal in implementing policies on preventing Covid-19. Conclusion: The conclusion of this study is that the government has not implemented a policy to prevent Covid-19 properly, especially in socialization and supervision efforts. Therefore, massive socialization and supervision efforts must be made and carried out jointly by the government and all stakeholders in the region in order to reduce the rate of increase in Covid 19.
\end{abstract}

Key words: public perception; goverment policy; Covid-19

\title{
PENDAHULUAN
}

Covid-19 adalah penyakit yang disebabkan oleh corona virus. Corona virus (CoV) merupakan bagian dari keluarga virus yang menyebabkan penyakit mulai dari flu hingga penyakit yang lebih berat seperti Middle East Respiratory Syndrome (MERS-CoV) and Severe Acute Respiratory Syndrome (SARS-CoV). Penyakit yang disebabkan virus corona, atau dikenal dengan Covid-19 adalah jenis baru yang ditemukan pada tahun 2019 dan belum pernah diidentifikasi menyerang manusia sebelumnya (Kemenkes RI, 2020).

Kasus terkonfirmasi positif Covid-19 menurut WHO adalah berjumlah 9.296.202 kasus dengan 479.133 jumlah kematian di 216 negara terjangkit. Di Indonesia kasus terkonfirmasi pada 25 Juni 2020 berjumlah 50.187 kasus dengan 2.620 kematian dan data di Sulawesi utara kasus konfirmasi berjumlah 938 kasus dan 70 kasus kematian (Kemenkes RI, 2020).

Data dari Puskesmas Tikala dan Ranomuut tercatat bahwa pada tanggal 19 Agustus 2020 terdapat kasus terkonfirmasi Covid-19 dengan Total 155 kasus, yang beberapa di antaranya merupakan kasus konfirmasi asimptomatik (orang tanpa gejala) dan ada yang di rawat di Rumah Sakit. Pasien yang di rawat di rumah sakit terdapat 2 orang pada tanggal 18 Agustus 2020, adapun 9 orang lainnya melakukan isolasi mandiri di rumah masing-masing dan 1 orang lainnya melakukan isolasi mandiri di rumah singgah. Adapun sisanya yang berjumlah 143 kasus sudah dinyatakan sembuh karena waktu melakukan swab test hasilnya negatif berdasarkan pedoman Covid-19 revisi ke-5 Kementerian Kesehatan RI. Ada sekitar 2 orang Ibu hamil yang merupakan suspek Covid-19 yang sudah di rujuk ke rumah sakit. Dalam data puskesmas pada tanggal 19 Agustus 2020 tidak adanya catatan bahwa terdapat kasus konfirmasi, ataupun yang dinyatakan suspek atau probable pada anak-anak, tetapi pada awal bulan April tercatat 
bahwa terdapat 1 kasus yang meninggal dikarenakan terkonfirmasi sebagai suspek dan juga pada bulan Juni terdapat 1 kasus meninggal karena terkonfirmasi suspek.

Upaya yang telah dilakukan oleh Kementerian Kesehatan adalah Penyampaian Surat Edaran Dirjen P2P mengenai Kesiapsiagaan dalam Upaya Pencegahan Penyebaran Penyakit Pneumonia dari Negara Republik Rakyat Tiongkok ke Indonesia kepada Dinas Kesehatan Provinsi/Kab/Kota, KKP, B/BTKL-PP, dan seluruh rumah sakit rujukan nasional dan regional, yang akan terus diperbarui sesuai dengan perkembangan situasi. Pelayanan kesehatan yang optimal dapat terwujud melalui tindakan pencegahan dan mitigasi. Beberapa langkah pencegahan yang diajurkan untuk diterapkan di masyarakat diantaranya, membersihkan tangan menggunakan hand sanitizer atau sabun cuci tangan, menghindari menyentuh mata, hidung dan mulut, menutup hidung dan mulut dengan lengan atas bagian dalam atau tisu jika batuk atau bersin dan buang tisu bekas di tempat sampah, memakai masker medis jika memiliki gejala gangguan pernapasan dan melakukan kebersihan tangan setelah membuang masker, menjaga jarak minimal 1 meter dari orang yang mengalami gejala gangguan pernapasan. (Pedoman Pencegahan Covid19, 2020).

Kebijakan yang dibuat oleh pemerintah akan berjalan baik bila ada dukungan dari lapisan masyarakat. Penelitian lain tentang pengetahuan masyarakat dengan kepatuhan menggunakan masker sebagai salah satu kebijakan di Kab. Ngronggah, menyebutkan ternyata memang ada hubungan antara pengetahuan dengan tindakan masyarakat yakni kepatuhan menggunakan masker sebagai upaya pencegahan penyakit COVID-19 di Kab. Ngronggah (Devi, 2020). Tujuan penelitian ini yaitu untuk menggambarkan persepsi masyarakat terhadap pelaksanaan kebijakan pemerintah tentang pencegahan Covid-19 di Kecamatan Tikala kota Manado.

\section{METODE PENELITIAN}

Penelitian ini merupakan studi observasional dengan rancangan penelitian cross sectional study. Penelitian ini dilakukan di kecamatan Tikala kota Manado pada 12-19 Agustus 2020. Subyek dalam penelitian ini yaitu masyarakat yang ada di Kecamatan Tikala kota Manado. Berhubung saat ini masih ada pembatasan aktifitas masyarakat maka pengambilan data dilakukan secara hati-hati sehingga metode penentuan subyek penelitian menggunakan metode purposif sampling dengan pertimbangan yaitu masyarakat yang bisa menerima dan bersedia diwawancarai oleh peneliti saat turun lapangan. Turun lapangan dilakukan selama 7 hari dan diperoleh sebanyak 100 kepala keluarga. Variabel dalam penelitian ini yaitu persepsi masyarakat tentang kebijakan pemerintah tentang pengendalian Covid 19. Instrumen penelitian menggunakan kuesioner yang telah di validasi secara konstruk. Pertanyaan yang ditanyakan yaitu tentang adanya kegiatan sosialisasi tentang upaya pengendalian Covid 19, pengawasan yang dilakukan pemerintah, pemeriksaan fisik dan memeriksa dokumen bagi masyarakat yang akan keluar masuk di kecamatan Tikala. Data hasil penelitian dianalisis secara univariat. Penyajian data dibuat dalam bentuk tabel dan narasi.

\section{HASIL DAN PEMBAHASAN}

Pertanyaan yang diajukan terdiri atas 4 pertanyaan tentang kebijakan pemerintah dalam upaya pencegahan Covid-19 seperti sosialisasi dan pengawasan yang dilakukan oleh pemerintah dalam 7 hari terakhir sejak dilakukan wawancara. Hal ini dapat dilihat pada Tabel 1. 
Tabel 1. Distribusi jawaban responden tentang kebijakan pemerintah

\begin{tabular}{|c|c|c|c|c|c|}
\hline \multirow[t]{2}{*}{ No } & \multirow[t]{2}{*}{ Pertanyaan } & \multicolumn{2}{|c|}{ Selalu } & \multicolumn{2}{|c|}{ Tidak selalu } \\
\hline & & n & $\%$ & $\mathbf{n}$ & $\%$ \\
\hline 1. & $\begin{array}{l}\text { Aparat kelurahan melakukan sosialisasi } \\
\text { (dalam bentuk pengumuman/ } \\
\text { penyuluhan atau kegiatan serupa } \\
\text { lainnya) terkait pencegahan Covid-19 di } \\
\text { kelurahan dalam } 7 \text { hari terakhir }\end{array}$ & 10 & 10,00 & 90 & 90,00 \\
\hline 2. & $\begin{array}{l}\text { Aparat kelurahan melakukan } \\
\text { pengawasan bagi warga atau masyarakat } \\
\text { luar yang keluar masuk kelurahan dalam } \\
7 \text { hari terakhir }\end{array}$ & 8 & 8,00 & 92 & 92,00 \\
\hline 3. & $\begin{array}{l}\text { Aparat kelurahan melakukan } \\
\text { pemeriksaan fisik berupa tes suhu tubuh } \\
\text { atau pemakaian masker warga yang } \\
\text { keluar masuk kelurahan dalam } 7 \text { hari } \\
\text { terakhir }\end{array}$ & 11 & 11,00 & 89 & 89,00 \\
\hline 4. & $\begin{array}{l}\text { Aparat kelurahan memeriksa dokumen } \\
\text { berupa surat keterangan sehat dari } \\
\text { instansi kesehatan seperti Puskesmas } \\
\text { dari warga yang keluar masuk kelurahan } \\
\text { dalam } 7 \text { hari terakhir }\end{array}$ & 11 & 11,00 & 89 & 89,00 \\
\hline & Rataan & & & & \\
\hline
\end{tabular}

Tabel 1 menunjukkan bahwa pada waktu penelitian ini (12-19 Agustus 2020) masyarakat memiliki persepsi bahwa pemerintah melakukan kebijakan seperti sosialisasi dan pengawasan hanya sekitar $10 \%$ dimana terendah tentang pelaksanaan pengawasan bagi masyarakat yang keluar masuk kelurahan dalam 7 hari terakhir yang hanya sebesar $8 \%$ dan tertinggi yaitu pemeriksaan suhu tubuh dan penggunaan masker oleh masyarakat serta adanya pemeriksaan surat keterangan sehat dari institusi kesehatan sebesar $11 \%$. Pandemi Covid-19 telah berdampak pada kesehatan masyarakat secara ekonomi dan sosial, maka sangat penting dilakukan upaya mengimplementasikan kebijakan tersebut untuk menghindari krisis dengan mengambil langkah-langkah yang efektif secara cepat di semua tingkatan. Penyebaran Covid-19 sudah meluas di seluruh penjuru dunia dan telah dinyatakan secara resmi oleh Organisasi Kesehatan Dunia (WHO) sebagai pandemi global. Oleh karenanya, diharapkan seluruh pihak dari berbagai aspek harus bekerja sama untuk menahan penyebaran virus, termasuk di tempat kerja. Dalam keterangan tertulis yang disampaikan oleh WHO, dinyatakan beberapa saran bagi para pekerja maupun institusi untuk meminimalisir risiko terinfeksi Covid-19 mulai dari pencegahan individu hingga tempat kerja. Pemerintah di berbagai negara di seluruh dunia melakukan upaya besar-besaran untuk mengendalikannya dengan menghimbau seluruh masyarakat umum dan pekerja, termasuk perusahaan/institusi dan pemberi kerja, harus berpartisipasi guna meraih keberhasilan dalam pengendalian pandemi tersebut (Poernomo, 2020).

Berdasarkan Kepmenkes RI Nomor HK.01.07/MENKES/247/2020 tentang Pedoman Pencegahan dan Pengendalian Covid-19 menyatakan bukti yang tersedia, Covid-19 ditularkan melalui kontak dekat dan droplet, bukan melalui transmisi udara. 
Orang-orang yang paling berisiko terinfeksi adalah mereka yang berhubungan dekat dengan pasien Covid-19 atau yang merawat pasien Covid-19 atau yang kontak erat dengan pasien tersebut. Tindakan pencegahan dan pengurangan risiko merupakan kunci penerapan di pelayanan kesehatan dan masyarakat. Langkah-langkah pencegahan yang paling efektif di masyarakat meliputi:

1. Melakukan kebersihan tangan dengan menggunakan air mengalir dan sabun jika tersedia atau menggunakan hand sanitizer setiap saat diperlukan; (sebelum dan sesudah menggunakan toilet, sebelum dan sesudah makan, sebelum dan sesudah menyentuh pasien, atau setelah terkena cairan tubuh pasien, setelah menyentuh benda/alat kantor lainnya, atau permukaan yang belum terjamin kebersihannya dan setelah meninggalkan lingkungan disekitar pasien atau lingkungan kerja).

2. Menghindari menyentuh mata, hidung dan mulut dengan tangan yang belum dicuci;

3. Terapkan etika batuk atau bersin dengan menutup hidung dan mulut dengan lengan atas bagian dalam atau tisu, lalu buanglah tisu ke tempat sampah;

4. Menggunakan masker pada saat keluar rumah atau pada saat ditempat kerja, menggunakan masker medis jika memiliki gejala pernapasan dan melakukan kebersihan tangan setelah membuang masker;

5. Menjaga jarak (minimal $1 \mathrm{~m}$ ) dari orang yang mengalami gejala gangguan pernapasan

6. Tidak melakukan jabat tangan, mengganti salam jabat tangan dengan salam yang lain

7. Menerapkan pola hidup bersih dan sehat (segera mandi dan mengganti pakaian setelah tiba dirumah)

8. Mengkonsumsi gizi seimbang (perbanyak makan sayur dan buah- buahan, mengkonsumsi vitamin)

9. Olahraga teratur untuk meningkatkan imunitas tubuh.

Penelitian yang dilakukan Utami, dkk (2020) yang dilakukan pada 1021 responden menunjukkan bahwa sebanyak $70,7 \%$ bersikap baik sedangkan 29,3\% bersikap kurang baik, namun kasus baru Covid-19 terus bertambah setiap hari lebih lanjut,penerapan new normal bukan berarti melonggarkan protokol kesehatan yang ada tetapi harus diimbangi dengan kepatuhan yang tinggi dari masyarakat. Sementara itu, studi literatur yang dilakukan Sagala, dkk (2020) menunjukkan bahwa sikap masyarakat terhdap kebijakan pemerintah dalam mencegah penularan Covid-19 masih rendah.Hal ini ditunjukkan dengan menjaga jarak (social distancing) masih terlihat rendah, karena warga beraktivitas keluar rumah untuk tujuan rekreasi, duduk bergerombol, berkumpul tanpa menggunakan masker ataupun menjaga jarak, sehingga kemungkinan penyebaran dapat meningkat. Penelitian yang dilakukan oleh Nungki dan Santoso (2012) Sekalipun sikap yang ditunjukan oleh masyarakat positif tetapi pengetahuan mengenai penyebab penyakit, gejala yang ditimbulkan, proses penularan dan pencegahan serta perilaku masyarakat yang tidak baik akan tetap berisiko dalam penularan penyakit.

\section{PENUTUP}

Kesimpulan dari penelitian ini yaitu masyarakat menilai bahwa pemerintah belum cukup baik melakukan melaksanakan kebijakan dalam rangka pengendalian Covid-19 di masyarakat sehingga masyarakat tidak memiliki pengetahuan yang tepat bahkan bisa terhasut oleh informasi-informasi yang tidak benar. Oleh karena itu, diharapkan agar pemerintah bisa melakukan upaya sosialisasi dan pengawasan yang lebih masif seperti penyuluhan yang dilakukan setiap minggu melalui alat pengeras suara, ibadah-ibadah keagamaan, radio, televisi dan media sosial agar masyarakat memperoleh informasi yang benar tentang upaya pencegahan Covid 19. 


\section{REFERENSI}

Gugus Tugas Percepatan Penanganan COVID-19. 2020. Hoax Buster. (https://covid19.go.id/p/hoax-buster/salah-video-di-balik-covid-19coronaternyata-isi-nya-sudah-habis)

Gugus Tugas Percepatan Penanganan COVID-19. 2020. Peta Sebaran. (https://covid19.go.id/peta-sebaran, diakses tanggal 06 Juni 2020).

Kementerian Kesehatan RI. 2020. Infeksi Emerging Media Informasi Resmi Terkini Penyakit Infeksi Emerging (https://covid19.kemkes.go.id diakses tanggal 06 Juni 2020).

Kementerian Kesehatan RI. 2020. Kesiapan Kemenkes dalam Menghadapi Outbreak Novel Coronavirus (2019-nCoV). Direktur Pencegahan dan Pengendalian Penyakit Tular Vektor dan Zoonosis Ditjen Pencegahan dan Pengendalian Penyakit Kementerian Kesehatan. Simposium PAPDI Forum.

Kementerian Kesehatan RI. 2020. Pedoman Pencegahan dan Pengendaian Coronavirus Disease (COVID-19) Jakarta: Direktorat Jendral Pencegahan dan PengendalianPenyakit (P2P).

Nuraini R. 2020. Kasus Covid-19 Pertama, Masyarakat Jangan Panik. Jakarta: indonesia.go.id (https://indonesia.go.id/narasi/indonesia-dalamangka/ekonomi/kasus-covid-19-pertama-masyarakat-jangan-panik diakses tanggal 18 Juli 2020)

Sagala S. H, Maifita Y, dan Armaita A. 2020.Hubungan Pengetahuan dan Sikap Masyarakat terhadap COVID-19 :A Literature Review. Pariaman: STIKes Piala Sakti Pariaman.

Sari P. D, Sholiha N dan Atiqoh.2020. Hubungan Antara Pengetahuan Masyarakat dengan Kepatuhan Penggunan Masker sebagai Upaya Pencegahan Penyakit COVID-19 di Ngronggah. Surakarta: Universitas Duta Bangsa. INFOKES Vol. 10 No 1.

Sulaeman dan Supriadi. 2020. Peningkatan Pengetahuan Masuarakat Desa Jelantik dalam Menghadapi Pandemi Corona Virus Disease-19 (COVID-19). Mataram: Universitas Pendidikan Mandalika Mataram.Vol 1. Pg: 21-17.

Sumampouw O. J dan Andarini S. 2016. Metode Penelitian dalam Kesehatan Masyarakat. Yogyakarta: Deepublish

WHO. 2020. Anjuran mengenai Penggunaan Masker dalam Konteks COVID-19. (https://www.who.int/docs/default-source/searo/indonesia/covid19/anjuranmengenai-penggunaan-masker-dalam-konteks-covid19.pdf?sfvrsn=8a209b04_2 , diakses pada tanggal 06 Juni 2020) 